\title{
Ralstonia solanacearum Race 3, Biovar 2 Strains Isolated from Geranium Are Pathogenic on Potato
}

\author{
Lynn Williamson, Department of Plant Pathology, University of Wisconsin-Madison, Madison 53711; Kazuhiro \\ Nakaho, Chugoku National Agricultural Experiment Station, Fukuyma, Hiroshima 721-8514 Japan, and Depart- \\ ment of Plant Pathology, University of Wisconsin-Madison, Madison 53711; Brian Hudelson, Department of Plant \\ Pathology, University of Wisconsin-Madison, Madison 53711; and Caitilyn Allen, Department of Plant Pathology, \\ University of Wisconsin-Madison, Madison 53711
}

\begin{abstract}
Williamson, L., Nakaho, K., Hudelson, B., and Allen, C. 2002. Ralstonia solanacearum race 3, biovar 2 strains isolated from geranium are pathogenic on potato. Plant Dis. 86:987-991.

Ralstonia solanacearum race 3 , biovar 2 is a soilborne bacterium that causes potato brown rot disease in temperate and subtropical climates. Recent outbreaks of this disease in Europe have caused serious losses, but the pathogen had not been identified in the United States. However, in 1999 , strains of $R$. solanacearum were isolated from wilting geraniums growing in Wisconsin greenhouses. Physiological and biochemical tests of the Wisconsin strains and a similar strain from South Dakota demonstrated that the strains belong to $R$. solanacearum subgroup biovar 2, which is largely synonymous with the race 3 subgroup, a classification based on host range. These results were confirmed by polymerase chain reaction analyses in which race 3, biovar 2specific primers amplified a fragment of the expected size. This is the first report of race 3 , biovar 2 in the United States, and it is the first known occurrence of race 3, biovar 2 in Wiscon$\sin$. The geranium strains were highly pathogenic on both geranium and potato. The presence of $R$. solanacearum race 3, biovar 2 in the United States raises concern that the bacterium could move from ornamental plants into potato fields, where it could cause both direct economic damage and quarantine problems. A commercial indirect enzyme-linked immunosorbent assay for $R$. solanacearum produced some false negatives for these strains, indicating that current indexing may not be sufficient to identify this destructive pathogen.
\end{abstract}

Ralstonia solanacearum (synonyms: Pseudomonas solanacearum and Burkholderia solanacearum) is a widespread and economically important bacterial plant pathogen $(15,24)$. It causes bacterial wilt, a major disease that limits production of diverse crops such as potato, tomato, peanut, and banana. $R$. solanacearum has an extended host range that includes hundreds of plant species in 44 families (15). The pathogen is widely distributed in tropical, subtropical, and warm temperate climates. The species is highly variable and heterogeneous.

Strains of $R$. solanacearum are differentiated into five races according to host range (3) and five biovars according to utilization of various disaccharides and hexose alcohols $(14,16)$. The race and biovar classifications do not correspond, except that race 3 is generally equivalent to biovar 2 (15). Biovars fall into two geographically distinct groups $(23,27)$. In general, division 1 , comprising biovars 3,4 ,

Corresponding author: C. Allen

E-mail: cza@plantpath.wisc.edu

Accepted for publication 9 May 2002.

Publication no. D-2002-0715-01R

(C) 2002 The American Phytopathological Society and 5, predominates in Australia and Asia. Division 2, including biovars 1 and 2, predominates in the Americas, although it should be noted that biovar 2, until now, has not been reported in the United States. Polymerase chain reaction (PCR) diagnostic tests have been developed for this bacterium, with $16 \mathrm{~S}$ rRNA and ITS primers that differentiate between divisions 1 and 2 and additional primers that are specific for biovar $2(2,23,31)$.

A distinct group of $R$. solanacearum (race 3, biovar 2) causes brown rot, a serious disease of potatoes $(15,17)$. This group has a host range primarily limited to potato, tomato, and common solanaceous weeds, although it has also been reported on stinging nettle where roots were growing in contaminated water (32) and on other non-solanaceous weeds under favorable conditions $(6,17,28)$. The strain is adapted to the cooler temperatures found at higher elevations and higher latitudes $(4,6,26)$. Intermittent but increasingly frequent brown rot outbreaks in northern Europe since 1972 have resulted in significant losses due both to disease incidence and to quarantine restrictions that require destruction of infected crops and fallowing of infested fields $(6,17)$. The bacteria were probably disseminated by latently infected tubers and contaminated irrigation water $(6,17,32)$. Although some reports claim that the bacterium does not survive longterm in soil $(6,12)$, it has overwintered in soils, waterways, and/or in roots of a perennial weed host, Solanum dulcamara, in Sweden, France, the UK, and the Netherlands $(8,21,30)$. To our knowledge, race 3 strains of $R$. solanacearum have not been reported in the United States.

In the spring of 1999, we isolated $R$. solanacearum from zonal geraniums, Pelargonium $\times$ hortorum, that were imported into Wisconsin from Guatemala. Geranium is known to be a natural host of $R$. solanacearum race $1(13,14,25)$ but only a casual report has identified race 3 on geranium to date (17). Our goals were to identify the race and biovar of $R$. solanacearum strains recovered from geranium and to characterize the pathogenicity of these strains.

\section{MATERIALS AND METHODS}

Bacterial strains. In April 1999, wilt symptoms were observed on geraniums obtained from greenhouses in Jefferson and Milwaukee counties in Wisconsin. The plants had been propagated from vegetative material imported from Guatemala. Bacteria were isolated from infected leaves and stems of the host plants, yielding strain BB-Feutz from Jefferson County, and BBEsser from Milwaukee County. Similar geranium strains of $R$. solanacearum (strains 12-4-5 WI, 12-4-6 SD, and 12-4-9 $\mathrm{NJ})$ were collected by the Long Island Horticultural Research Laboratory. These strains were compared with various strains of $R$. solanacearum (race 1/biovar 1 strain K60; race 1/biovar 4 strains UW130 and GMI1000; race 2/biovar 1 strain UW9; and race 3/biovar 2 strains UW72, UW257, UW272, UW276, and UW344) from a collection at the Department of Plant Pathology, University of Wisconsin, Madison (Table 1).

Cultural and physiological tests. Tests for Gram stain, and oxidase and catalase activity followed procedures described in Schaad et al. (22) and Gerhardt et al. (10). The strains were grown on yeast dextrose calcium carbonate medium (YDC) to assess color and on King's B medium amended with $100 \mathrm{ppm}$ cycloheximide $(\mathrm{KB}+\mathrm{C})$ for fluorescence $(22)$. The isolates were routinely cultured on casamino acidspeptone-glucose (CPG) and triphenyltetrazolium chloride medium (TZC) (18). 
To test for oxidation of sugars and sugar alcohols, $5 \mathrm{ml}$ each of glucose, trehalose, maltose, or mannitol $(10 \% \mathrm{wt} / \mathrm{vol})$ solutions were filter sterilized and added to 45 $\mathrm{ml}$ of Hayward's medium, and 10-ml volumes of the resulting amended medium were dispensed into test tubes (14). Hayward's medium without a sugar or sugar alcohol carbon source served as a control. A suspension was prepared of each test strain (BB-Feutz, BB-Esser, and 12-4-6 biovar 2 (UW72 and UW272), and biovar 3 (UW130) by inoculating $300 \mu \mathrm{l}$ of sterile water with a wire loopful of cells from each strain grown on CPG for $48 \mathrm{~h}$ at $28^{\circ} \mathrm{C}$. The test tubes of Hayward's media were inoculated with $30 \mu \mathrm{l}$ of the prepared suspensions and incubated at $24^{\circ} \mathrm{C}$ for up to 5 weeks.

Hypersensitive reaction. Ability to induce a hypersensitive reaction (HR) on tobacco was determined for BB-Feutz and 12-4-6 SD following the method of Lozano and Sequeira (19). Tobacco (Nicotiana tabacum L. 'Bottom Special') leaves were infused with a bacterial suspension spectrophotometrically adjusted to $A_{600}=0.16$ to 0.18 (approximately $1.7 \times 10^{8} \mathrm{CFU} / \mathrm{ml}$ ). A similar suspension of GMI1000, an $R$. solanacearum strain known to induce an HR on tobacco, served as a positive control and sterile water as a negative control. Observations were taken at 12-h intervals for the first 3 days and at 24-h intervals for an additional 4 days.

PCR identification of race 3 strains. Ten strains of $R$. solanacearum were tested with race 3, biovar 2-specific primers. For each strain, a biovar 2-specific DNA fragment was amplified by PCR using a modioriginally adapted from the PCR protocol of Fegan et al. (9). Oligonucleotide primers B2-I-F and B2-II-R were used. Reactions were conducted in thin-walled $250-\mu \mathrm{l}$ tubes and contained $50 \mathrm{ng}$ of template chromosomal DNA; 10 pmol of each primer; 1 unit of Taq DNA Polymerase (Promega Corp., Madison, WI); $0.25 \mathrm{mM}$ each of ATP, CTP, GTP, and TTP; and $2.5 \mathrm{mM}$ $\mathrm{Mg}^{++}$in a $30-\mu$ l volume of $1 \times$ Promega Taq Polymerase Buffer without magnesium. SD) and control strains of biovar 1 (K60), fication of the protocol of Weller et al. (31)

The PCR reactions were amplified in an MJ Research Model PTC-200 thermocycler under the following conditions: a 5min hot start at $94^{\circ} \mathrm{C}$ was followed by 40 cycles of $30 \mathrm{~s}$ at $94^{\circ} \mathrm{C}, 30 \mathrm{~s}$ at $70^{\circ} \mathrm{C}$, and 1 min at $72^{\circ} \mathrm{C}$. The reaction was completed with $10 \mathrm{~min}$ at $72^{\circ} \mathrm{C}$, and then reactions were stored at $4^{\circ} \mathrm{C}$. Because DNA yield was typically low, two separate reactions were combined, precipitated with ethanol, and resuspended in $20 \mu \mathrm{l}$ of water before being separated on a $2.0 \%(\mathrm{wt} / \mathrm{vol})$ agarose gel. DNA product bands were visualized under UV light after staining with ethidium bromide.

Indirect enzyme-linked immunosorbent assay (ELISA). Test strains BBFeutz and 12-4-6 SD, and control strains K60, UW276, and UW344, were sent in 1999 to Agdia Testing Services (Agdia Inc., Elkhart, IN; 219/264-2014) for their indirect ELISA for $R$. solanacearum. Tests were performed twice and repeated in spring 2002 with a new antiserum.

Pathogenicity testing. Koch's postulates were performed with 'Americana Reds' geranium and 'Bonny Best' tomato as hosts. After a 24 -h period without water, roots of each plant were cut $1 \mathrm{~cm}$ from the stem on one side, and approximately $10 \mathrm{ml}$ of an aqueous suspension of BB-Feutz spectrophotometrically adjusted to $A_{600}=$ 0.1 to 0.5 (approximately 1 to $5 \times 10^{8}$ $\mathrm{CFU} / \mathrm{ml}$ ) was poured around the base of the stem. Controls were mock inoculated with water. Plants were placed in a greenhouse at 20 to $31^{\circ} \mathrm{C}$ and observed daily.

BB-Feutz and 12-4-6 SD were tested for pathogenicity on potato (Solanum tuberosum 'Atlantic') and geranium (Pelargonium $\times$ hortorum 'Melody'). Potatoes were multiplied in tissue culture and transplanted to $10-\mathrm{cm}$ pots containing Scotts Redi-earth plug and seedling mix (ScottsSierra Horticultural Products Co., Marysville, $\mathrm{OH})$. Commercially indexed, rooted cuttings of geraniums were similarly planted. Plants were grown for 1 month in a $28^{\circ} \mathrm{C}$ growth chamber and watered with Hoagland's solution (5).

After a 24-h period without water, groups of 26 potato plants were inoculated with one of the following treatments: BB-

Table 1. Ralstonia solanacearum strains used in this study

\begin{tabular}{lcccc}
\hline Strain & Race & Biovar & Host & Origin \\
\hline K60 & 1 & 1 & Tomato & NC, USA \\
UW130 & 1 & 3 & Tomato & Peru \\
GMI1000 & 1 & 4 & Tomato & French Guyana \\
UW9 & 2 & 1 & Heliconia & Costa Rica \\
UW72 & 3 & 2 & Potato & Greece \\
UW257 & 3 & 2 & Potato & Costa Rica \\
UW272 & 3 & 2 & Potato & Costa Rica \\
UW276 & 3 & 2 & Potato & Mexico \\
UW344 & 3 & 2 & Potato & Brazil \\
BB-Esser & 3 & 2 & Geranium & WI, USA \\
BB-Feutz & 3 & 2 & Geranium & WI, USA \\
12-4-5 WI & 3 & 2 & Geranium & WI, USA \\
12-4-6 SD & 3 & 2 & Geranium & SD, USA \\
12-4-9 NJ & 3 & 2 & Geranium & NJ, USA \\
\hline
\end{tabular}

Feutz, 12-4-6 SD, UW 344 (a positive control), or sterile water (a negative control). Roots were cut $1 \mathrm{~cm}$ from the stem on one side, and approximately $20 \mathrm{ml}$ of an aqueous suspension of each strain, spectrophotometrically adjusted to $A_{600}=0.8$ (approximately $8 \times 10^{8} \mathrm{CFU} / \mathrm{ml}$ ), was poured around the base of the stem (33). Inoculated plants and controls mock inoculated with water were placed in a growth chamber at 28 to $30^{\circ} \mathrm{C}$ with a 12 -h photoperiod and watered every second or third day with Hoagland's solution. Treatments were arranged in a randomized complete block design with 26 replications of each treatment. Plants were subsequently recoded so they could be rated for disease blindly. The same experimental design was used for geraniums, except that $30 \mathrm{ml}$ of an aqueous suspension of each strain was poured around the base of the stems.

Plants were evaluated daily for the percentage of the leaves that were wilted $(0=$ no leaves wilted, $100=$ all leaves wilted or dead). Data were converted to proportions and then transformed using an arcsine square root transformation. Transformed values were subsequently analyzed using a repeated measures analysis of variance (ANOVA) (20).

\section{RESULTS}

Cultural and physiological characteristics. Typically for $R$. solanacearum, the three geranium strains (BB-Feutz, BB-Esser, and 12-4-6 SD) were gram negative, oxidase positive, and catalase positive. On CPG medium, colonies were irregular, smooth, creamy white, and fluidal, and produced a brown pigment after $48 \mathrm{~h}$. Colony morphology was similar on TZC medium, except that colonies were off-white with red centers. All strains produced cream-colored colonies on YDC; none of the strains fluoresced on King's B medium.

On Hayward's medium, strains BBFeutz, BB-Esser, and 12-4-6 SD produced acid, causing a complete indicator change with glucose in 2 to 6 days and maltose in 11 to 18 days, but they did not utilize trehalose or mannitol even after 28 days (Table 2). No reaction was produced in inoculated media without a carbohydrate source. Based on these results, all three strains were classified as biovar 2 in accordance with Hayward (14) and $\mathrm{He}$ et al. (16).

Koch's postulates. Seven to 10 days after inoculation, geraniums inoculated with BB-Feutz and 12-4-6 SD were wilted and chlorotic, and 3 weeks after inoculation they were largely dead. One week after inoculation, tomato plants were fully wilted, and all inoculated plants were dead after 2 weeks. Bacteria reisolated from wilted plants had cultural characteristics typical of $R$. solanacearum. No wilting was observed in the noninoculated control plants. These results demonstrated that strains BB-Feutz and 12-4-6 SD were the 
pathogens responsible for the wilt disease originally observed in geranium plants.

Hypersensitivity. Neither BB-Feutz nor 12-4-6SD elicited a classic rapid HR on slower tissue collapse typical of compatible interactions. Tobacco leaves infiltrated with BB-Feutz were mottled light green by $15 \mathrm{~h}$ after inoculation; this color change gradually spread to the entire infiltrated area by $48 \mathrm{~h}$. By $60 \mathrm{~h}$, the infiltrated leaf areas were fully collapsed and brown. They were either sharply delimited from the healthy green noninoculated tissue or surrounded by a narrow light-green halo. Strain 12-4-6 SD elicited a more rapid response; infiltrated leaves remained symptomless until $48 \mathrm{~h}$ after inoculation, but then infiltrated areas became brown, necrotic, and surrounded with a narrow light-green halo. After 5 days, lesions of both strains were similar and had not spread to adjoining tissue. In contrast, tobacco leaves infiltrated with strain GMI1000, which is known to elicit an HR on tobacco, became collapsed, tan, and papery within $15 \mathrm{~h}$ after inoculation. Areas infiltrated with water were unaffected.

PCR. The race 3, biovar 2-specific PCR primers of Weller et al. (31) amplified the predicted 68-bp DNA product from the geranium strains BB-Feutz, BB-Esser, 124-5 WI, 12-4-6 SD, and 12-4-9 NJ (Fig. 1, tobacco leaves, although they did elicit a

lanes 1 to 5). This 68-bp product derives from the highly variable internal transcribed spacer region between the $16 \mathrm{~S}$ and $23 \mathrm{~S}$ rDNA genes. The 68-bp band was not amplified from DNA of the biovar 1 and 4 control strains (K60 and GMI1000) (Fig. 1, lanes 9 and 10) but was consistently amplified from all of the known race 3, biovar 2 strains (Fig. 1, lanes 6 to 8). Thus, these five geranium isolates of $R$. solanacearum contain DNA sequences unique to race 3 , biovar 2 , strongly supporting their classification in this group.

Indirect ELISA. Neither geranium strains BB-Feutz and 12-4-6 SD, nor known race 3 , biovar 2 control strains UW276 and UW344, were identified in 1999 as $R$. solanacearum by indirect ELISA in tests conducted by Agdia Testing Services. However, these tests did identify the race 1, biovar 1 positive control K60 as $R$. solanacearum. A second round of Agdia ELISAs with a new antiserum in spring 2002 did identify most, but not all, geranium strains as $R$. solanacearum.

Pathogenicity. Geranium strains BBFeutz, 12-4-6 SD, and race 3, biovar 2 control strain UW344 were all highly pathogenic on both potato and geranium. Lower leaves of both hosts began to wilt by approximately 5 days after inoculation.

On potato, disease development was significantly different among treatments,

Table 2. Oxidation of carbohydrates by strains of Ralstonia solanacearum

\begin{tabular}{lccccc}
\hline & \multicolumn{5}{c}{ Acid production from carbohydrates } \\
\cline { 2 - 6 } Strain & $\begin{array}{c}\text { Glucose }+ \\
\text { control }\end{array}$ & $\begin{array}{c}\text { Water }- \\
\text { control }\end{array}$ & Trehalose & Maltose & Mannitol \\
\hline BB-Feutz & $+_{+++^{\mathrm{a}}}$ & - & - & ++ & - \\
BB-Esser & +++ & - & - & + & - \\
12-4-6 SD & +++ & - & - & + & - \\
UW72 (biovar 2) & +++ & - & - & + & - \\
K60 (biovar 1) & +++ & - & ++ & - & - \\
UW130 (biovar 3) & +++ & - & ++ & w & + \\
\hline
\end{tabular}

a $+++=$ Complete indicator change 2 to 6 days; $++=$ complete indicator change 6 to 14 days; $+=$ complete indicator change 14 to 21 days; $-=$ no indicator change up to 28 days; $w=$ partial indicator change at 14 to 21 days.

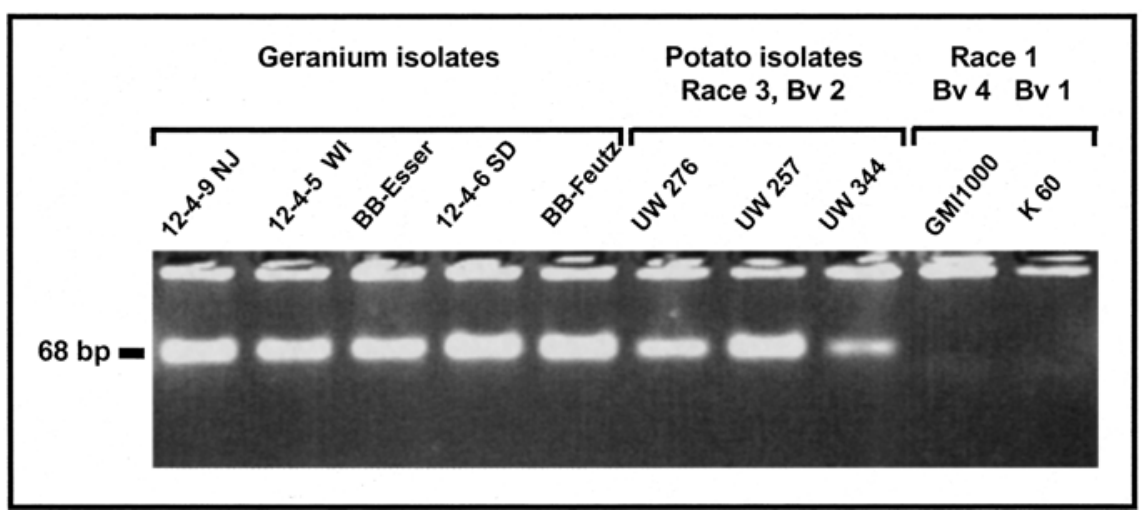

Fig. 1. Electrophoretic analysis of polymerase chain reaction (PCR)-amplified DNA from Ralstonia solanacearum isolates using the primers B2-I-F and B2-II-R of Weller et al. (31). Lane 1, geranium isolate 12-4-6 NJ; lane 2, geranium isolate 12-4-5 WI; lane 3, geranium isolate BB-Esser; lane 4, geranium isolate 12-4-6 SD; lane 5, geranium isolate BB-Feutz; lane 6, UW276 (race 3, biovar 2); lane 7, UW257 (race 3, biovar 2); lane 8, UW344 (race 3, biovar 2); lane 9, GMI1000 (race 1, biovar 4); lane 10, K60 (race 1, biovar 1). and between inoculated and noninoculated controls (Fig. 2). Disease progressed most rapidly on potatoes inoculated with BBFeutz. By 28 days postinoculation, 100\% of potato plants inoculated with BB-Feutz, $90 \%$ of potato plants inoculated with UW344, and $70 \%$ of potato plants inoculated with 12-4-6 SD were severely wilted (80 to $100 \%$ of leaves wilted) or dead (Fig. 2 ), whereas none of the mock inoculated potato controls were wilted.

On geranium, disease development was significantly different between inoculated and noninoculated controls, but not significantly different among bacterial strains (Fig. 3). By 28 days postinoculation, $88 \%$ of geraniums inoculated with BB-Feutz, $84 \%$ of geraniums inoculated with UW344, and $96 \%$ of geraniums inoculated with 12-4-6 SD were severely wilted or dead (Fig. 3). At 28 days, one of the mock inoculated geranium controls had wilt symptoms.

\section{DISCUSSION}

Strains of $R$. solanacearum were isolated from wilted geraniums obtained from

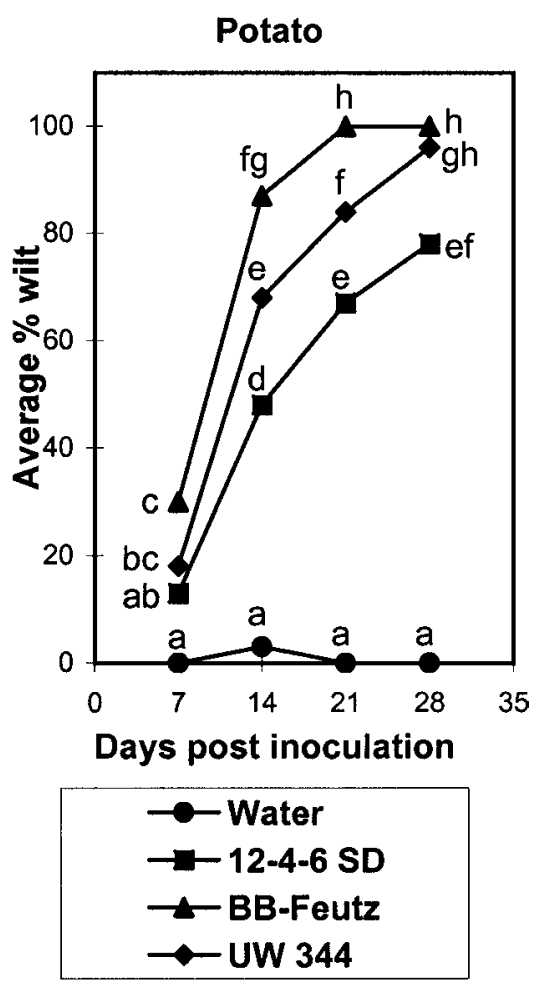

Fig. 2. Pathogenicity of Ralstonia solanacearum on potato. Plants were evaluated for the percentage of leaves wilted $(0=$ no leaves wilted, $100=$ all leaves wilted or dead). The "average \% wilt" represents the average of 26 ratings from individual plants in each treatment. Disease values that are labeled with different letters are significantly different from each other $(P=0.05)$ based on a repeated measures ANOVA of arcsine square root transformed proportions derived from these data, followed by comparisons of transformed means using protected LSDs. 
Wisconsin, New Jersey, and South Dakota in 1999. Physiological tests demonstrated that the strains belong to biovar 2, which is essentially synonymous with race 3 . Pathogenicity tests revealed that these strains are highly pathogenic on potato and tomato, suggesting that they have the host range typical of race 3 . Finally, race 3 , biovar 2-specific PCR primers amplified a DNA fragment of the expected size from all five geranium strains tested. Collectively, these results conclusively demonstrate that the causal agent of the geranium wilt is $R$. solanacearum race 3, biovar 2 .

This is the first report of race 3, biovar 2 in the United States, and it is the first known occurrence of race 3, biovar 2 in Wisconsin. Previously, only $R$. solanacearum race 1 , biovar 1 had been reported in the United States. Geranium is known to be a natural host of $R$. solanacearum. However, this host has not generally been associated with race 3 , biovar 2 ; the previous report of $R$. solanacearum on geranium in the United States did not identify the pathogen to biovar (25). The one European report that identified the Pelargonium hor-

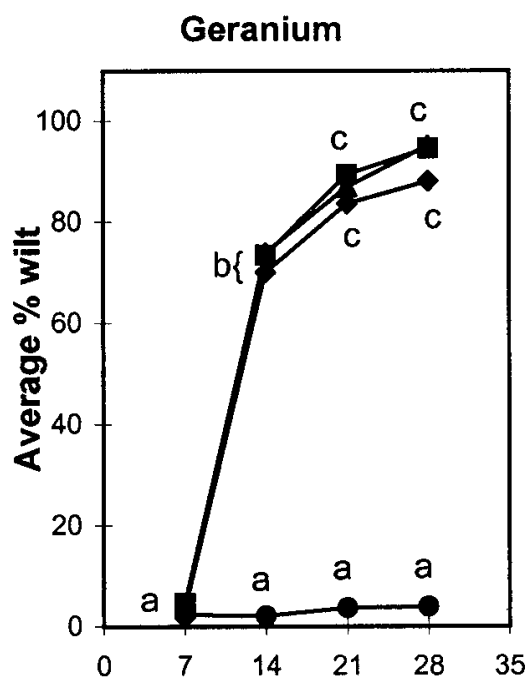

Days post inoculation

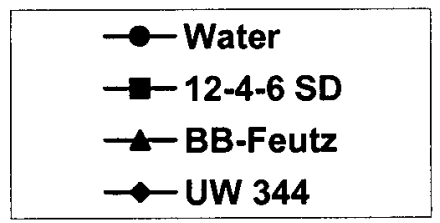

Fig. 3. Pathogenicity of Ralstonia solanacearum on geranium. Plants were evaluated for the percentage of leaves wilted $(0=$ no leaves wilted, $100=$ all leaves wilted or dead). The "average \% wilt" represents the average of 26 ratings from individual plants in each treatment. Disease values that are labeled with different letters are significantly different from each other $(P=0.05)$ based on a repeated measures ANOVA of arcsine square root transformed proportions derived from these data, followed by comparisons of transformed means using protected LSDs. torum pathogen as race 3 called the occurrence a "remarkable fact that has largely gone unnoticed" (17).

It is of considerable concern that the race 3 , biovar 2 strains isolated from geranium were aggressively pathogenic on potato and tomato in greenhouse conditions. This finding raises the disturbing possibility that the bacterium could move from ornamental plants originally grown in the tropics to potato fields in temperate North America. It is not known how active race 3 , biovar 2 would be under field conditions in Wisconsin, or whether it could successfully overwinter here.

Experience with $R$. solanacearum race 3 , biovar 2 in Europe suggests what could happen in the United States. Prior to the 1970 s, brown rot was thought to be exclusively a disease of the tropics and subtropics. However, sporadic brown rot outbreaks were reported in Sweden in 1972, in Belgium in 1989, in the Netherlands and the UK in 1992, and in France, Portugal, and Italy in 1994 (17); further sporadic outbreaks have continued. Epidemiological studies demonstrated that the bacterium can overwinter in buried potato tubers, in the roots of $S$. dulcamara, a common perennial weed that grows along waterways $(6,21,17)$, in soil, and in surface water $(29,30)$. Investigations in European countries suggested that the brown rot disease outbreaks were mainly caused by contaminated irrigation water or by latently infected seed potatoes. In cases associated with contaminated water, the source of bacteria may have been effluent from potato processing or water-treatment plants that handled diseased potatoes $(6,17)$. In addition, the pathogen infected $S$. dulcamara, leached from diseased roots, and subsequently infected potatoes irrigated with the water. It is unlikely that $R$. solanacearum can now be eradicated from European countries, since eradication may depend on removal of host weeds and decontamination of rivers and irrigation canals. S. dulcamara, introduced from Europe, is naturalized throughout the northeastern United States (11) and is thus a potential weed host in Wisconsin. As it is common practice for greenhouses to dispose of diseased plants by tossing them into an open waste container or a compost pile, it is not difficult to imagine ways in which the pathogen could enter surface water and become established in the northern United States.

The increasing number of disease outbreaks caused by $R$. solanacearum race 3 , biovar 2 in temperate environments emphasizes the need for efficient diagnostic tests. Current indexing in the United States, which commonly depends on ELISA, may not be sufficient to identify this destructive race/biovar. As with any serological test, antibodies used in indirect ELISA may not react with all strains of a species. In our case, indirect ELISA con- ducted by Agdia Testing Services produced false negatives for the race 3 , biovar 2 strains tested, indicating that this test may be unable to detect all race 3 , biovar 2 strains. Dialogue is continuing with Agdia, and a reconstituted test for $R$. solanacearum is underway. Further research is necessary to determine the reliability of ELISA for detecting race 3 , biovar 2, and to determine whether Wisconsin strains are antigenically distinct from other race 3 , biovar 2 strains.

Improved detection of race 3 , biovar 2 may be possible by using a combination of techniques. Several effective diagnostic methods for $R$. solanacearum have been developed in recent years, including detection of DNA sequences following PCR amplification $(2,23,31)$, fluorescent in situ hybridization (FISH) (34), and modified semi-selective SMSA media (7). These methods, as well as ELISA, have advantages and disadvantages in sensitivity, specificity, and practicality (7). The test scheme currently used in the European community to detect $R$. solanacearum incorporates a combination of methods. Initial screening may be made by a rapid diagnostic strip ELISA or colony immunofluorescence antibody staining (IFAS) using antiserum with the demonstrated ability to recognize race 3 , biovar 2 , or by selective plating with modified SMSA, in all cases with additional confirmation using ELISA, PCR, and other tests. Final identification uses one or more of the following techniques: nutritional and enzymatic tests, IFAS, PCR, FISH, protein profiling, or fatty acid profiling. Finally, pathogenicity is tested on tomato or eggplant (1). We recommend that a similar testing scheme using a combination of methods be followed in the United States to more reliably detect $R$. solanacearum, including race 3 , biovar 2 .

\section{ACKNOWLEDGMENTS}

We thank Huayu Huang, Darlene Gakovich, and Julie Tans-Kersten for their technical assistance; Oglevee Ltd. (152 Oglevee Lane, Connellsville, PA) for providing geranium cuttings; and the Long Island Horticultural Research Laboratory, Cornell University, for providing $R$. solanacearum cultures. Thanks also to Dr. and Mrs. Donald Hagedorn, who established the Hagedorn Scholarship in Plant Pathology Fund, which partially funded this work.

\section{LITERATURE CITED}

1. Anonymous. 1997. 97/647/EC: Commission decision of 9 September 1997 detailing an interim test scheme for the diagnosis, detection and identification of Pseudomonas solanacearum (Smith) Smith in potatoes. Official journal NO.L273, 06/10/1997 P.0001-0025.

2. Boudazin, G., LeRoux, A. C., Josi, K., Labarre, P., and Jouan, B. 2000. Design of division specific primers of Ralstonia solanacearum and application to the identification of European isolates. Eur. J. Plant Pathol. 105:373-380

3. Buddenhagen, I. W., Sequeira, L., and Kelman, A. 1962. Designation of races in Pseudomonas solanacearum. (Abstr.) Phytopathology 52:726. 
4. Ciampi, L., and Sequeira, L. 1980. Influence of temperature on virulence of race 3 strains of Pseudomonas solanacearum. Am. Potato J. 57:307-317.

5. Dhingra, O. D., and Sinclair, J. B. 1985. Basic Plant Pathology Methods. CRC Press, Boca Raton, FL. p. 317.

6. Elphinstone, J. G. 1996. Survival and possibilities for extinction of Pseudomonas solanacearum (Smith) Smith in cool climates. Potato Res. 39:403-410.

7. Elphinstone, J. G., Hennessy, J., Wilson, J. K., and Stead, D. E. 1996. Sensitivity of different methods for the detection of Ralstonia solanacearum in potato tuber extracts. Bull. OEPP/EPPO Bull. 26:663-678.

8. Elphinstone, J. G., Stanford, H. M., and Stead, D. E. 1998. Detection of Ralstonia solanacearum in potato tubers, Solanum dulcamara and associated irrigation water. Pages 133-139 in: Bacterial Wilt Disease: Molecular and Ecological Aspects. P. Prior, C. Allen, and J. Elphinstone, eds. Springer-Verlag, Berlin.

9. Fegan, M., Holoway, G., Hayward, A. C., and Timmis, J. 1998. Development of a diagnostic test based on the polymerase chain reaction (PCR) to identify strains of $R$. solanacearum exhibiting the biovar 2 genotype. Pages 34-43 in: P. Prior, C. Allen, and J. Elphinstone, eds. Bacterial Wilt Disease: Molecular and Ecological Aspects. Springer-Verlag, Berlin.

10. Gerhardt, P., Murray, R. G. E., Costilow, R. N., Nester, E. W., Wood, W. A., Krieg, N. R., and Phillips, G. B., eds. 1981. Manual of Methods for General Bacteriology. American Society for Microbiology, Washington, DC. p. 413.

11. Gleason, H. A., and Cronquist, A. 1991. Manual of Vascular Plants of Northeastern United States and Adjacent Canada. 2nd ed. New York Botanical Garden, Bronx, New York. p. 404.

12. Graham, J., Jones, D. A., and Lloyd, A. B. 1979. Survival of Pseudomonas solanacearum race 3 in plant debris and in latently infected potato tubers. Phytopathology 69:1100-1103.

13. Hammer, P. A., and Rane, K. 1999. Southern bacterial wilt found in geraniums. GrowerTalks 63:80-82.

14. Hayward, A. C. 1964. Characteristics of Pseudomonas solanacearum. J. Appl. Bacte- riol. 27:265-277.

15. Hayward, A. C. 1991. Biology and epidemiology of bacterial wilt caused by Pseudomonas solanacearum. Annu. Rev. Phytopathol. 29:65-87

16. He, L. Y., Sequeira, L., and Kelman, A. 1983. Characteristics of strains of Pseudomonas solanacearum from China. Plant Dis. 67:13571361.

17. Janse, J. D. 1996. Potato brown rot in Western Europe - History, presence occurrence and some remarks on possible origin, epidemiology and control strategies. Bull. OEPP/EPPO Bull. 26:679-985.

18. Kelman, A. 1954. The relationship of pathogenicity in Pseudomonas solanacearum to colony appearance in a tetrazolium medium. Phytopathology 44:693-695.

19. Lozano, J. C., and Sequeira, L. 1970. Differentiation of races of Pseudomonas solanacearum by a leaf infiltration technique. Phytopathology 60:833-838.

20. Milliken, G. A., and Johnson, D. E. 1998. Analysis of Messy Data. Chapman \& Hall/CRC Press, Boca Raton, FL. pp. 355356.

21. Olsson, K. 1976. Experience of brown rot caused by Pseudomonas solanacearum (Smith) Smith in Sweden. Bull. OEPP/EPPO Bull. 6:199-207.

22. Schaad, N. W., Jones, J. B., and Chun, W. eds. 2001. Laboratory Guide for Identification of Plant Pathogenic Bacteria. 3rd ed. American Phytopathological Society, St. Paul, MN. pp. 4-10.

23. Seal, S. E., Taghavi, M., Fegan, N., Hayward, A. C., and Fegan, M. 1999. Determination of Ralstonia (Pseudomonas) solanacearum rDNA subgroups by PCR tests. Plant Pathol. 48:115-120.

24. Sequeira, L. 1993. Bacterial wilt: Past, present, and future. G. L. Hartman and A. C. Hayward, eds. Bacterial Wilt. ACIAR Proceedings No. 45.

25. Strider, D. L., Jones, R. K., and Haygood, R. A. 1981. Southern bacterial wilt of geranium caused by Pseudomonas solanacearum. Plant Dis. 65:52-53.

26. Swanepoel, A. 1990. The effect of temperature on the development of wilting and on progeny tuber infection of potatoes inoculated with South African strains of biovar 2 and 3 of Pseudomonas solanacearum. Potato Res. 33:287-290.

27. Taghavi, M., Hayward, C., Sly, L. I., and Fegan, M. 1996. Analysis of the phylogenetic relationships of strains of Burkholderia solanacearum, Pseudomonas syzygii, and the blood disease bacterium of banana based on $16 \mathrm{~S}$ rRNA gene sequences. Int. J. Syst. Bacteriol. 46:10-15.

28. Tusiime, G., Adipala, E., Opio, F., and Bhagsari, A. S. 1998. Weeds as latent hosts of Ral stonia solanacearum in highland Uganda: Implications to development of an integrated control package for bacterial wilt. Pages 413419 in: Bacterial Wilt Disease: Molecular and Ecological Aspects. P. Prior, C. Allen, and J. Elphinstone, eds. Springer-Verlag, Berlin

29. Van Elsas, J. D., Kastelein, P., de Vries, P. M. and van Overbeek, L. S. 2001. Effects of ecological factors on the survival and physiology of Ralstonia solanacearum bv. 2 in irrigation water. Can. J. Microbiol. 47(9):842-854.

30. Van Elsas, J. D., Kastelein, P., van Bekkum, P., van der Wolf, J. M., de Vries, P. M., and van Overbeek, L. S. 2000. Survival of Ralstonia solanacearum biovar 2 , the causative agent of potato brown rot, in field and microcosm soils in temperate climates. Phytopathology 90:1358-1366.

31. Weller, S. A., Elphinstone, J. G., Smith, N. C. Boonham, N., and Stead, D. E. 2000. Detection of Ralstonia solanacearum strains with quantitative, multiplex, real-time fluorogenic PCR (TaqMan) assay. Appl. Environ. Microbiol. 66:2853-2858.

32. Wenneker, M., Verdel, M. S. W., Groeneveld, R. M. W., Kempenaar, C., van Beuningen, A. R., and Janse, J. D. 1999. Ralstonia (Pseudomonas) solanacearum race 3 (biovar 2) in surface water and natural weed hosts: First report on stinging nettle (Urtica dioica). Eur. J Plant Pathol. 105:307-315.

33. Winstead, N. N., and Kelman, A. 1952. Inoculation techniques for evaluating resistance to Pseudomonas solanacearum. Phytopathology 42:628-634.

34. Wullings, B. A., Van Beuningen, A. R., Janse, J. D., and Akkermans, A. D. L. 1998. Detection of Ralstonia solanacearum, which causes brown rot of potato, by fluorescent in situ hybridization with 23S rRNA-targeted probes Appl. Environ. Microbiol. 64:4546-4554 